\title{
Monitoring, calibration and maintenance of optimized nutrient solutions in curly lettuce (Lactuca sativa, L.) hydroponic cultivation
}

\author{
Antonio Fernandes Monteiro Filho ${ }^{1}$, Carlos Alberto Vieira de Azevedo ${ }^{2,3^{*}}$, Márcia Rejane de Queiroz \\ Almeida Azevedo ${ }^{1}$, Josely Dantas Fernandes ${ }^{1}$, Carisa Rocha da Silva ${ }^{1}$, Pedro Dantas Fernandes ${ }^{2,4}$
}

${ }^{1}$ State University of Paraíba, Center of Environmental and Agrarian Sciences, Lagoa Seca, 58.117-000, Paraíba, Brazil ${ }^{2}$ Federal University of Campina Grande, Academic Unit of Agricultural Engineering, Campina Grande, 58.429-140, Paraíba, Brazil

${ }^{3}$ Fellow of CNPq Research Productivity, level 1B, Brazil

${ }^{4}$ Fellow of CNPq Research Productivity, level 1A, Brazil

*Corresponding author: cvieiradeazevedo@gmail.com

\begin{abstract}
The monitoring, calibration and maintenance of nutrient solutions are fundamental for the development of hydroponic lettuce. This study aimed to monitor temperature, electrical conductivity, hydrogen potential and consumption of nutrient solution, besides evaluating the effectiveness of the Microsoft Office Excel SOLVER tool in the calibration of different mineral and organomineral nutrient solutions in the NFT hydroponic cultivation of curly lettuce. The experiment was conducted in randomized blocks with three replicates and the treatments consisted of four mineral solutions proposed by Furlani, Bernardes, Ueda and Castellane and Araújo, besides four organomineral nutrient solutions, proposed in this research, with chemical composition similar to the previously cited ones. For 24 days, the nutrient solutions were monitored and the variations of temperature, $\mathrm{pH}$, electrical conductivity (EC) and nutrient solution consumption by the crop were measured. Calibrations were made using the Microsoft Excel SOLVER tool, using as reference an EC of $1.5 \mathrm{dS} \mathrm{m}^{-1}$ and nutrient solution volume of $17 \mathrm{~L}$. During the experiment, regardless of the nutrient solution (modified and mineral), temperature showed maximum and minimum values of 28.7 and $21.5 \stackrel{\circ}{\circ}$, respectively, and $\mathrm{pH}$ variation was lower in the modified nutrient solutions. Water consumption was higher with the use of mineral solutions, in comparison to the organomineral solutions with the same chemical composition. The SOLVER tool was efficient and easily used in the calibration and maintenance of electrical conductivity and volume of the nutrient solutions.
\end{abstract}

Keywords: Lactuca sativa, L., hydroponics, SOLVER.

Abbreviations: BM_mineral nutrient solution of Bernardes (1997); FM_mineral nutrient solution of Furlani (1995); CM_mineral nutrient solution of Castellane and Araújo (1994); UM_mineral nutrient solution of Ueda (1990); BO_modified nutrient solution of Bernardes (1997); FO_modified nutrient solution of Furlani (1995); CO_modified nutrient solution of Castellane and Araújo (1994); UO_modified nutrient solution of Ueda (1990); BIO1_biofertilizer used in the modified solution of Ueda (1990); BIO2_biofertilizer used in the modified solution of Castellane and Araújo (1994); BIO3_biofertilizer used in the modified solution of Furlani (1995); BIO4_biofertilizer used in the modified solution of Bernardes (1997): TH_cultivar Thaís; VA_cultivar Vanda; VE_cultivar Verônica; E.V.A_Ethylene-vinyl acetate.

Introduction

Hydroponics is a technology in which different vegetable crops are cultivated in nutrient solution with or without the presence of an artificial medium (washed sand, gravel, vermiculite, coconut fiber, carbonized rice husk, sawdust, among others), which will serve as mechanical support for root development (Furtado, 2008). According to Factor (2007), the hydroponic system can be classified as open (after application, the nutrient solution is not reused) or closed (the nutrient solution is recovered, replenished and recycled). In the hydroponic cultivation, roots received a balanced nutrient solution that contains water and all nutrients necessary for plant development (Barbieri et al., 2010). Compared with the conventional cultivation, the hydroponic system has advantages for the consumer, producer and environment, generating products with high quality, short cycle, higher yield, less use of water, agricultural inputs and labor (Paulus et al., 2012; Lopes et al., 2003). The NFT system is basically composed of a tank of nutrient solution, a pumping system, two cultivation channels and a system of return to the tank. The nutrient solution is pumped to the channels and flows by gravity, forming a thin film of solution that irrigates the roots (Santos and Minami, 2002). The solution used in hydroponic systems must have all nutrients that are essential for plant development and there may be variations in the chemical composition and concentration, depending on the crop to be cultivated. Many studies have already been conducted with hydroponic cultivation of lettuce, such as Paulus et al. 
(2010), Paulus et al. (2012), Alves et al. (2011), Santos et al. (2011) and Sarmento et al. (2014). However, all refer to the use of mineral nutrient solutions. Regarding the use of organic solution, some studies have already been carried out, such as Dias et al. (2009), Ribeiro et al. (2007) and Monteiro Filho et al. (2017) using biofertilizer as nutrient solution. The supply of nutrients at adequate levels reduces production losses and increases the quality of hydroponic lettuce. Hence, it is essential to adequately control (monitor) the nutrient solution. The main factors to be controlled are the hydrogen potential $(\mathrm{pH})$, electrical conductivity $(\mathrm{EC})$ and temperature. In general, producers in many regions of Brazil use $\mathrm{pH}$ values close to 6.0, temperature of $27^{\circ} \mathrm{C}$ and $\mathrm{EC}$ ranging from 0.75 to $2.6 \mathrm{dS} \mathrm{m}^{-1}$ (Genúncio et al., 2012; Gondim et al., 2010; Barbiere et al., 2010). In hydroponic system, the producers face the challenge of maintaining the ideal balance between these parameters. Thus, both cultivation and calibration of the nutrient solutions must be performed with caution. Another parameter to be considered in hydroponic systems is the consumption of nutrient solution. For leafy vegetables, it is known that reductions in consumption are observed with the increment in solution salinity, causing decrease in plant osmotic potential, absorption of nutrient, evapotranspiration and crop development and production (Soares et al., 2010, Silva et al., 2012). Hence, periodic maintenance and calibrations of the nutrient solutions regarding the concentration are necessary. According to Braccini et al. (1999), the maintenance and renewal of the nutrient solutions can be performed based on the maximum depletion of nutrient, electrical conductivity (EC) and nutrient absorption curves, constant addition of nutrient solution and flow of ions, among others. The EC method is widely used by farmers, because of its practicality and cost. However, its calibration for desired levels becomes difficult, since the addition of nutrients directly influences the concentration of the solution. The utilization of EC calibration curves and the SOLVER tool of Microsoft Office Excel can be an alternative to solve such problem. For being a tool for decision-taking and optimization of processes (Monteiro Filho et al., 2014), the SOLVER tool calculates the volume of solution that will be removed from the tank, the volume of stock solution that will be added and, when necessary, the water volume to be replaced in the tank to reach the EC level that is adequate for the crop. Given the difficulty to maintain adequate levels of nutrients in nutrient solutions, the present study aimed to calibrate nutrient solutions based on electrical conductivity using the Microsoft Office Excel SOLVER tool, besides monitoring the variations of temperature, hydrogen potential and consumption of nutrient solutions.

\section{Results and discussion}

\section{Temperature of the nutrient solutions}

The daily recorded values of temperature in all nutrient solutions (modified and mineral) were similar, with minimum of $21.5{ }^{\circ} \mathrm{C}$ at 17 days and maximum of $28.7^{\circ} \mathrm{C}$ at 19 days (Fig. 1). The variation of only $7.2 \stackrel{\circ}{\circ}$ that occurred along the experiment is probably attributed to the thermal isolation of the tanks with EVA. It should be highlighted that the temperature readings of the nutrient solutions were taken at 14:00 $\mathrm{h}$ and that, inside the protected environment (greenhouse), the recorded minimum and maximum values were $16^{\circ} \mathrm{C}$ and $38^{\circ} \mathrm{C}$, respectively (Fig. 2).

The temperature of the nutrient solutions is an important parameter to be monitored in hydroponic cultivation because, according to Cometti et al. (2013), nutrient solution temperature affects the oxygen content and, in lettuce, high temperature can cause root death. According to Sanches et al. (2005), the difficulties in producing lettuce plants with well-formed heads in the hydroponic system, under adverse climate conditions, are due to, among other factors, high temperature in the region of the root system. Such high temperatures can cause problems of phytosanitary and nutritional order in the plants, especially due to the low availability of oxygen to the roots.

Extreme temperatures may be harmful to the metabolic processes occurring in plant tissues, such as absorption of nutrient, formation of chlorophyll and photosynthesis (Wahid et al., 2007; Yang et al., 2009; Al-Hamdani and Ghazal, 2009; Mohammed and Tarpley, 2009). In addition, the dissolved oxygen in the aqueous medium decreases with the increase in solution temperature, and the $\mathrm{O}_{2}$ demand by roots also increases under this condition, becoming more significant when the crops produce a dense mass of roots (Sutton et al., 2006). According to Martinez et al. (1997), $O_{2}$ solubility in water at $28{ }^{\circ} \mathrm{C}$ is $7.9 \mathrm{mg} \mathrm{L}^{-1}$, whereas at $45{ }^{\circ} \mathrm{C}$ it is only $6.1 \mathrm{mg} \mathrm{L}^{-1}$. Still according to these authors, when air and solution temperatures increase from 18 to 45 으 and from 23 to $28 \stackrel{\circ}{\circ}$, respectively, the dissolved $\mathrm{O}_{2}$ decreases from $78 \%$ to $66 \%$, i.e., from 6.5 to $5.2 \mathrm{mg} \mathrm{L}^{-1}$, even with constant air injection.

\section{pH and electrical conductivity of the nutrient solutions}

The acidity or alkalinity of nutrient solutions is indicated by the measurement of the concentration of hydrogen ions $\left(\mathrm{H}^{+}\right)$, being represented by the $\mathrm{pH}$ scale. Solutions with $\mathrm{pH}$ equal to 7.0 are considered as neutral, and values below or above neutrality characterize acidity and alkalinity, respectively. According to Martinez and Clemente (2011), in hydroponic systems the adequate range of this parameter for the lettuce crop is between 5.5 and 6.5. However, during crop development, alterations in the hydrogen concentration occurred due to the consumption of the nutrient solution by plants (Fig. 3).

According to Fig. 3, for the mineral solutions (Fig. 3B), there was a higher buffering power of the modified nutrient solutions (Fig. 3A), whose variation along the experiment was from 8.3 to 4.3 , against 7.9 to 3.3 of the mineral solution. However, $\mathrm{pH}$ values lower than 5.0 were recorded only with the utilization of the nutrient solution of Castellane and Araújo (1994) at 12 and 13 days after transplanting. The same behavior was not observed using the mineral solutions, which showed $\mathrm{pH}$ values above 5.0 during almost all the evaluation period. It is true that humic and fulvic substances have a buffering effect on soil pH (Dobbss et al., 2008). Regarding the nutrient solutions used in hydroponic system, Monteiro Filho et al. (2014) also found similar results, evaluating the use of modified nutrient solutions optimized with the SOLVER tool.

The results obtained in the present study are promising, considering that $\mathrm{pH}$ maintenance is one of the most laborious operations in experiments on nutrient solutions because, since they do not exhibit buffering power, their 
acidity or alkalinity needs to be daily adjusted to an adequate $\mathrm{pH}$ range, through the addition of a basic or acid solution, respectively (Braccini et al., 1999). According to Fonseca et al. (2005), the utilization of buffering agents is important for both research and farmers, since it perfects the operations of $\mathrm{pH}$ correction of the nutrient solutions. In addition, $\mathrm{pH}$ causes indirect effect on the solubility of nutrients; at high values, there may be formation of precipitates of some elements, such as calcium, phosphorus, iron and manganese, which are no longer available to plants (Gomes et al., 2011).

Still according to Figs. $3 \mathrm{~A}$ and $3 \mathrm{~B}$, there were $\mathrm{pH}$ variations in the solutions with values below neutrality, at 11, 22 and 13 days and above neutrality, at 7, 8 and from 14 days on, with the utilization of the modified solutions FO, BO and $\mathrm{UO}$. For mineral solutions, there was acidification in almost the entire evaluation period. This result may be associated with the imbalance in the absorption of cations and anions because, as it is known, anionic absorptions, such as the nitrate ion $\left(\mathrm{NO}_{3}{ }^{-}\right)$, lead to increase of solution $\mathrm{pH}$ through the release of bicarbonates $\left(\mathrm{HCO}_{3}{ }^{-}\right)$or hydroxyls $\left(\mathrm{OH}^{-}\right)$by the roots, and the opposite occurs for cations, such as the ammonium ion $\left(\mathrm{H}^{+}\right)$(Braccini et al., 1999). Another factor that justifies the trend of acidification of the mineral solutions is that the $\mathrm{pH}$ of the stock solutions was acidic, decreasing the $\mathrm{pH}$ of the solution, even after addition of the $\mathrm{NaOH}$ base, because it does not neutralize $\mathrm{H}^{+}$ions completely.

Oscillations in the electric conductivity (EC) are related to the consumption of water and nutrients by plants and to the evaporation of the nutrient solutions occurred during the experiment. According to Figs. $3 \mathrm{C}$ and $3 \mathrm{D}$, there was a variation of EC above and below the adjustment value (1.5 $\mathrm{dS} \mathrm{m}^{-1}$ ), indicating dilution and increase in the concentration of the nutrients, respectively. This last condition may be associated with the temperature recorded inside the protected environment, because at high temperatures plants absorb more water than nutrients, due to the high transpiration rate. As a final result, the solution becomes more concentrated and, therefore, with higher EC. The highest reductions in the EC value were only observed on the $15^{\text {th }}$ day after transplanting, since from this period on there is a greater dry matter accumulation in the plant, resulting from the higher absorption of nutrients and, consequently, reduction in the nutrient solution EC (Beninni et al., 2005).

Based on Figs. 3C and 3D, it is noted that the EC calibration was successfully performed because the EC was adjusted to $1.5 \mathrm{dS} \mathrm{m}^{-1}$, regardless of the utilized solution, using the SOLVER tool. The oscillations observed in the present study occurred in an interval of $24 \mathrm{~h}$ and the lowest and highest values were 1.05 and $1.85 \mathrm{dS} \mathrm{m}^{-1}$, respectively, for the utilization of the mineral solutions of Bernardes (1997) and Castellane and Araújo (1994). Some authors diverge on the ideal EC range to be used in lettuce hydroponic cultivation, which may vary according to the cultivar and climatic conditions (Helbel Júnior et al., 2007). However, Barbieri et al. (2010) lettuce planting in hydroponic system, in hot climate, must be performed using nutrient solutions with EC between 0.75 and $1.5 \mathrm{dS} \mathrm{m}^{-1}$.

\section{Nutrient solution consumption by lettuce plants}

According to the analysis of variance (Table 1), it is noted that the nutrient solution consumption by curly lettuce, in all treatments, was significant $(p<0.01)$, and the means fitted to quadratic polynomial regression models for the nutrient solutions FM, UM, BM, CM, FO and $\mathrm{CO}$. For the nutrient solutions $\cup O$ and $\mathrm{BO}$, the linear regression model showed the best fit (Table 1).

In the first days after transplanting (DAT), there were no major variations in the consumption of the modified nutrient solutions FO and CO; however, from 10 DAT on, the consumption by curly lettuce plants increased. With the utilization of the nutrient solutions $\mathrm{UO}$ and $\mathrm{BO}$, the absorption of solution was increasing along the entire evaluation period, whose unit increase, per day, was 0.0094 and $0.003 \mathrm{~L}$, respectively (Fig. $4 \mathrm{~A}$ ). For the mineral solutions, water consumption also showed no major variations in the first days after transplanting. However, from 8 DAT on, there was a significant increase in the consumption, characterizing well the difference between the tested solutions, whose highest means were recorded in the last evaluation period (Fig. 4B).

The mean consumption ( $L$ plant ${ }^{-1}$ day $^{-1}$ ) of each nutrient solution, in the period of $24 \mathrm{DAT}$, occurred in the following decreasing order: BM (0.143), FM (0.127), UO (0.119), CM (0.107), FO (0.106), UM (0.101), CO (0.097) and BO (0.074) (Table 1). Variations in consumption due to different lettuce cultivars have also been reported in the literature. Sanchez (2007), using the solution of Furlani (1995) and EC of $1.7 \mathrm{dS}$ $\mathrm{m}^{-1}$ in NFT hydroponic system, observed water consumption of $0.327,0.242,0.215,0.165$ and $0.149\left(\right.$ L plant $^{-1}$ day $^{-1}$ ) at 28 DAT, for the cultivars 'Crespona gigante', 'Verônica', 'Locarno', 'Pira Vermelha' and 'Pira Roxa', respectively.

Still regarding the mean water consumption (Table 1), the lowest values recorded in the utilization of the modified solutions, compared with the mineral solutions of same chemical composition, may be associated with the phytomass production, which showed mean values $(\mathrm{g})$ of 223.50 (BM), 190.20 (FM), 145.80 (CM), 108.31 (UM), 88.83 (FO), 77.75 (BO), 69.48 (CO) and 40.21 (UO). According to Paulus et al. (2012), the increment in water consumption by lettuce plants indicates an increase in transpiration, resulting from an increase in the photosynthetic rate and a greater phytomass production.

\section{Maintenance of the nutrient solutions}

Tables 2 and 3 describe the removed volumes of solution that supplied the hydroponic gutters and the additions of tank water and stock solution calculated using the SOLVER tool.

The monitoring and calibration of the solutions started at 2 DAT, with the record of the evapotranspired volume, as well as the adjustment of all nutrient solutions evaluated in the present study. In certain evaluation periods, such as 11 and 12 DAT, with the utilization of the mineral solution of Furlani (1995) (Table 2), it was necessary to remove 0.77 and $0.22 \mathrm{~L}$ of solution, respectively, from the tank that supplied the gutter. Every time this operation was performed, the 
Table 1. Analysis of variance for nutrient solution consumption by curly lettuce as a function of the mineral solutions of Furlani (1995) (FM), Ueda (1990) (UM), Bernardes (1997) (BM) and Castellane and Araújo (1990) (CM) and modified solutions of Furlani (1995) (FO), Ueda (1990) (UO), Bernardes (1997) (BO), and Castellane and Araújo (1994) (CO).

\begin{tabular}{|c|c|c|c|c|c|c|c|c|c|}
\hline \multirow{2}{*}{ Source of variation } & \multirow{2}{*}{ DF } & \multicolumn{8}{|c|}{ Mean square } \\
\hline & & $\mathrm{FM}$ & UM & $\mathrm{BM}$ & $\mathrm{CM}$ & $\mathrm{FO}$ & UO & $\mathrm{BO}$ & $\mathrm{CO}$ \\
\hline Water consumption & 23 & $0.024^{* *}$ & $0.012^{* *}$ & $0.027^{\text {** }}$ & $0.014^{* *}$ & $0.014^{* *}$ & $0.016^{* *}$ & $0.003^{* *}$ & $0.010^{* *}$ \\
\hline Linear & 1 & $0.459^{* *}$ & $0.212^{* *}$ & $0.518^{* *}$ & $0.252^{* *}$ & $0.233^{* *}$ & $0.304^{* *}$ & $0.0338^{* *}$ & $0.174^{* *}$ \\
\hline Quadratic & 1 & $0.025^{* *}$ & $0.026^{* *}$ & $0.029^{* *}$ & $0.015^{* *}$ & $0.017^{* *}$ & $0.001^{\mathrm{ns}}$ & $0.0003^{\mathrm{ns}}$ & $0.008^{* *}$ \\
\hline Deviation & 21 & $0.003^{* *}$ & $0.002^{* *}$ & $0.003^{* *}$ & $0.002^{* *}$ & $0.003^{* *}$ & $0.003^{\mathrm{ns}}$ & $0.0015^{* *}$ & $0.002^{* *}$ \\
\hline Block & 2 & $0.01^{* *}$ & $0.005^{* *}$ & $0.001^{\mathrm{ns}}$ & $0.0005^{\mathrm{ns}}$ & $0.0004^{\mathrm{ns}}$ & $0.009^{* *}$ & $0.0014^{*}$ & $0.002^{*}$ \\
\hline Residual & 46 & 0.001 & 0.0009 & 0.0009 & 0.0008 & 0.0008 & 0.002 & 0.0003 & 0.0006 \\
\hline CV (\%) & & 28.81 & 26.72 & 21.37 & 26.71 & 28.26 & 35.11 & 25.56 & 25.13 \\
\hline $\begin{array}{l}\text { Overall mean } \\
\left(\text { L plant }^{-1} \text { day }^{-1)}\right)\end{array}$ & & 0.127 & 0.101 & 0.143 & 0.107 & 0.106 & 0.119 & 0.074 & 0.097 \\
\hline
\end{tabular}

${ }^{D F}$ Degrees of freedom, ${ }^{* *}$ significant $(p<0.01)$, " significant $(p<0.05)$, ${ }^{\text {ns }}$ not significant $(p>0.05)$.

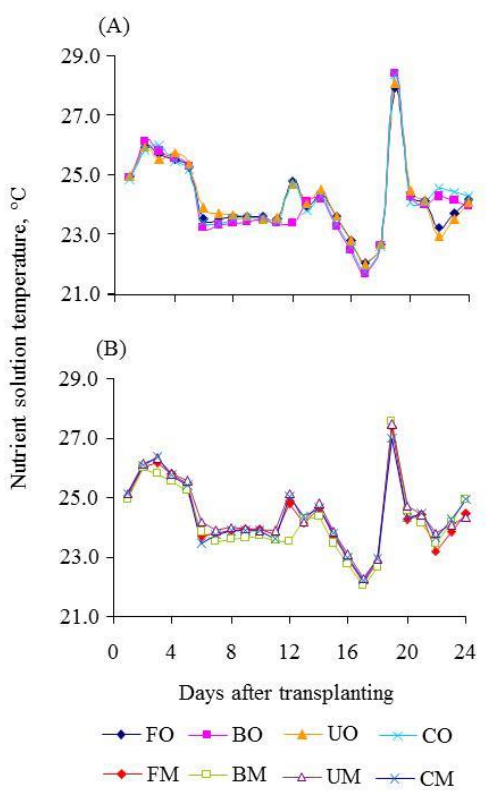

Fig 1. Variation of temperature for the modified nutrient solutions (A) of Furlani (1995) (FO), Bernardes (1997) (BO), Ueda (1990) (UO), and Castellane and Araújo (1994) (CO), and mineral solutions (B) of Furlani (1995) (FM), Bernardes (1997) (BM), Ueda (1990) (UM), and Castellane and Araújo (1994) (CM) during the experiment.

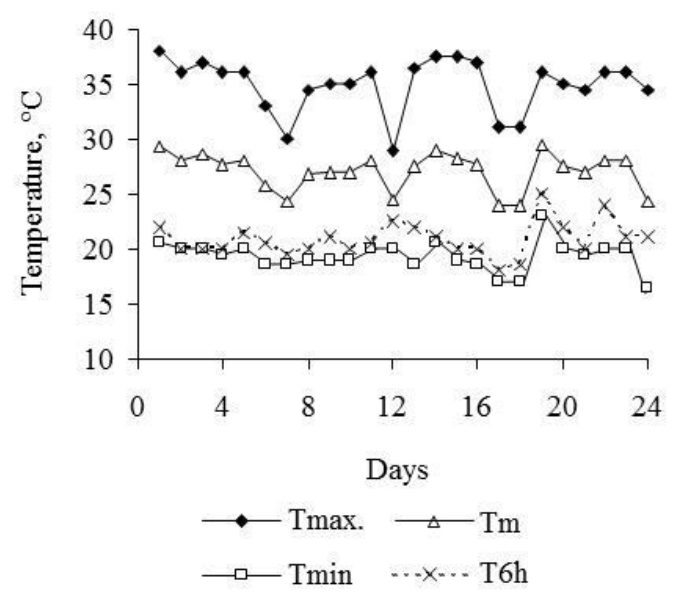

Fig 2. Data of maximum temperature (Tmax), minimum temperature ( $T$ min), mean temperature $(\mathrm{Tm})$ and temperature recorded at 06:00 a.m. (T6h) during the experiment. 
(A)

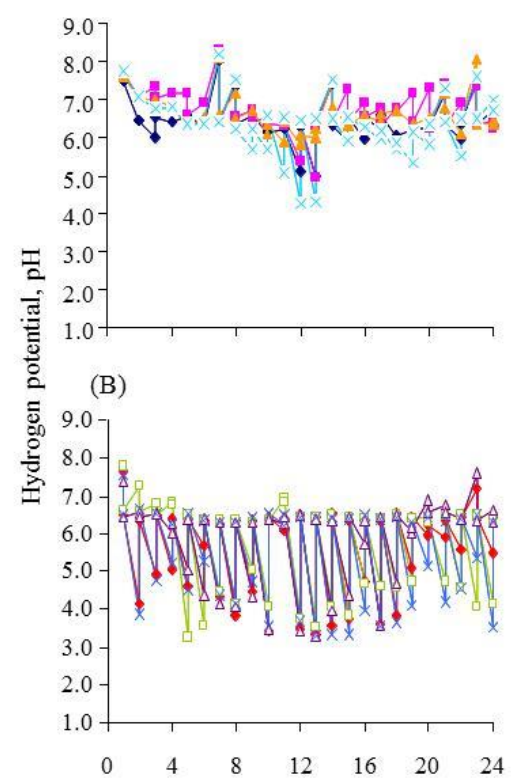

(C)

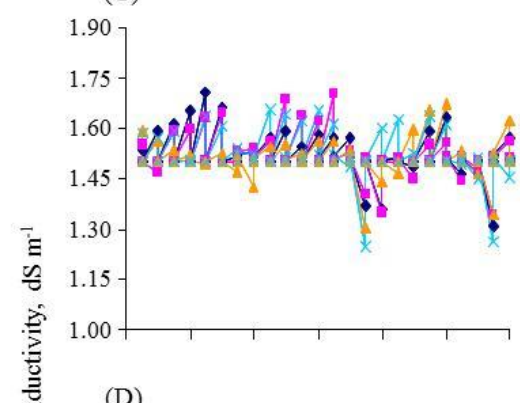

(D)

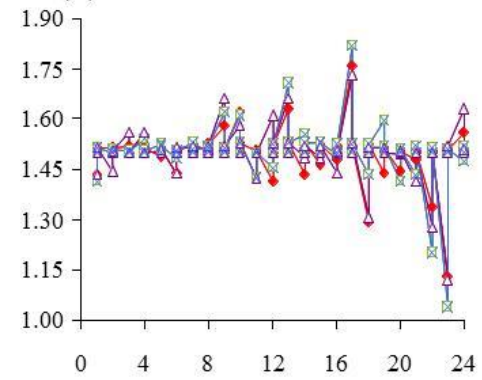

Days after transplantation

$$
\begin{aligned}
& \rightarrow \mathrm{FO} \rightarrow \mathrm{BO} \triangleleft \mathrm{UO} \leftarrow \mathrm{CO} \\
& \rightarrow \mathrm{FM} \rightarrow \mathrm{BM} \rightarrow \mathrm{UM} \rightarrow \mathrm{CM}
\end{aligned}
$$

Fig 3. Variation of hydrogen potential $(A$ and $B$ ) and electrical conductivity ( $C$ and $D)$ of the modified nutrient solutions of Furlani ( 1995) (FO), Bernardes (1997) (BO), Ueda (1990) (UO), and Castellane and Araújo (1994) (CO), and mineral nutrient solutions of Furlani (1995) (FM), Bernardes (1997) (BM), Ueda (1990) (UM), and Castellane and Araújo (1994) (CM).

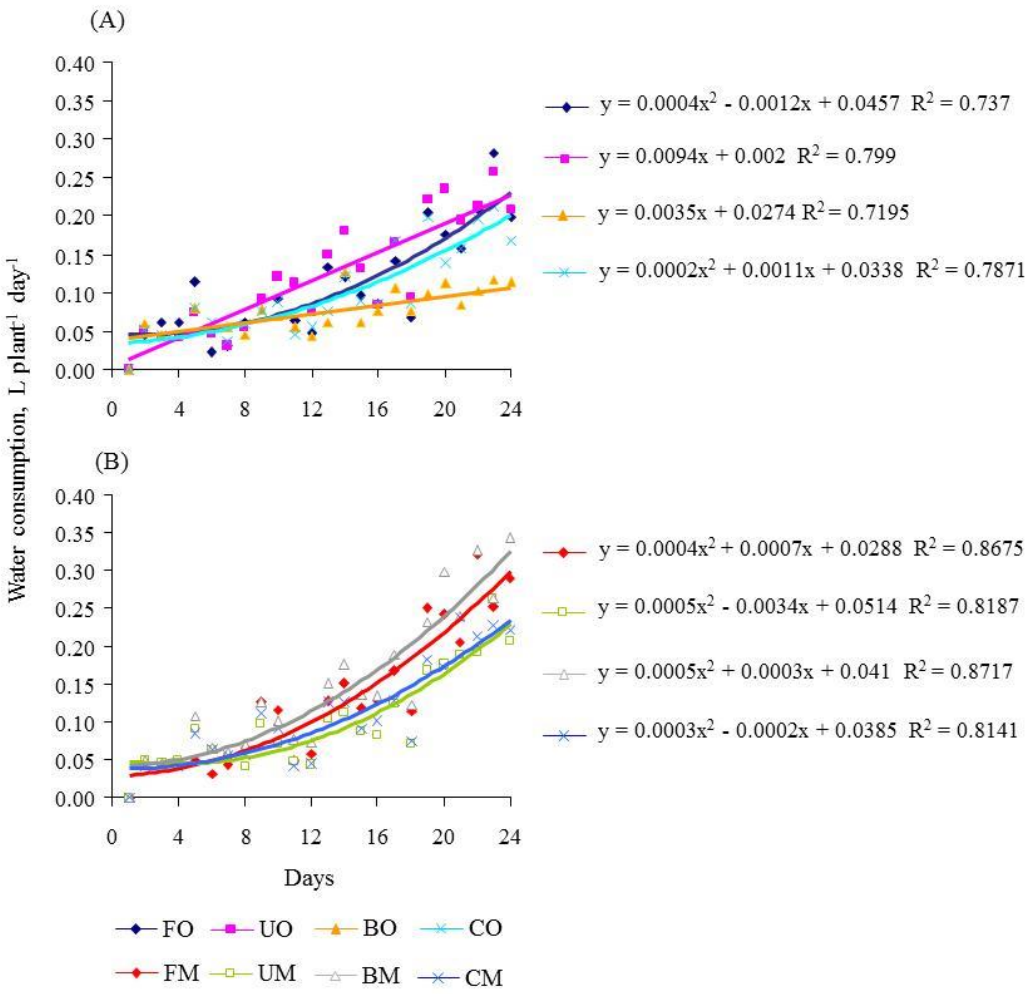

Fig 4. Nutrient solution consumption by curly lettuce along the experiment as a function of the modified nutrient solutions (A) of Furlani (1995) (FO), Bernardes (1997) (BO), Ueda (1990) (UO), and Castellane and Araújo (1994) (CO) and mineral solutions (B) of Furlani (1995) (FM), Bernardes (1997) (BM), Ueda (1990) (UM), and Castellane and Araújo (1994) (CM). 


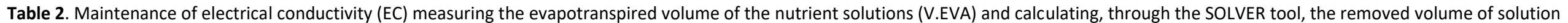
(V.REM) and additions of water (V.W) and stock solution (V.S.S) in the tanks, in order to maintain $17 \mathrm{~L}$ of mineral nutrient solution and EC of $1.5 \mathrm{dS} \mathrm{m}^{-1}$.

\begin{tabular}{|c|c|c|c|c|c|c|c|c|c|c|c|c|c|c|c|c|}
\hline \multirow{3}{*}{ Evaluation, days } & \multicolumn{4}{|c|}{ Furlani (1995) - mineral } & \multicolumn{4}{|c|}{ Bernardes (1997) - mineral } & \multicolumn{4}{|c|}{ Ueda (1990) - mineral } & \multicolumn{4}{|c|}{ Castellane and Araújo (1994) - mineral } \\
\hline & V.EVA & V.REM & V.W & V.S.S & V.EVA & V.REM & V.W & V.S.S & V.EVA & V.REM & V.W & V.S.S & V.EVA & V.REM & V.W & V.S.S \\
\hline & \multicolumn{16}{|c|}{ 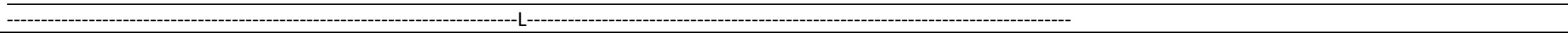 } \\
\hline 1 & 0.00 & 0.00 & 0.00 & 0.00 & 0.00 & 0.00 & 0.00 & 0.00 & 0.00 & 0.00 & 0.00 & 0.00 & 0.00 & 0.00 & 0.00 & 0.00 \\
\hline 2 & 0.91 & 0.00 & 0.73 & 0.18 & 1.01 & 0.00 & 0.75 & 0.26 & 1.01 & 0.00 & 0.58 & 0.43 & 0.81 & 0.00 & 0.61 & 0.20 \\
\hline 3 & 0.91 & 0.00 & 0.69 & 0.22 & 0.91 & 0.00 & 0.72 & 0.20 & 0.91 & 0.00 & 0.59 & 0.32 & 0.81 & 0.00 & 0.59 & 0.22 \\
\hline 4 & 0.91 & 0.12 & 0.85 & 0.19 & 0.91 & 0.00 & 0.61 & 0.30 & 1.01 & 0.00 & 0.74 & 0.29 & 0.81 & 0.04 & 0.73 & 0.13 \\
\hline 5 & 0.99 & 0.10 & 0.75 & 0.34 & 2.14 & 0.00 & 0.13 & 0.29 & 1.84 & 0.90 & 2.30 & 0.44 & 1.72 & 0.00 & 1.14 & 0.57 \\
\hline 6 & 0.61 & 0.03 & 0.22 & 0.42 & 1.32 & 0.00 & 0.69 & 0.63 & 1.26 & 0.00 & 1.03 & 0.22 & 1.29 & 0.00 & 0.92 & 0.38 \\
\hline 7 & 0.85 & 0.07 & 0.78 & 0.14 & 1.21 & 0.00 & 0.80 & 0.40 & 1.03 & 0.05 & 0.40 & 0.68 & 1.11 & 0.00 & 0.88 & 0.22 \\
\hline 8 & 1.32 & 0.00 & 0.87 & 0.44 & 1.42 & 0.00 & 0.90 & 0.51 & 0.81 & 0.00 & 0.54 & 0.27 & 1.11 & 0.00 & 0.77 & 0.34 \\
\hline 9 & 2.53 & 0.00 & 1.89 & 0.63 & 2.53 & 0.00 & 0.91 & 1.62 & 1.94 & 0.00 & 1.46 & 0.48 & 2.23 & 0.00 & 1.60 & 0.61 \\
\hline 10 & 2.33 & 0.00 & 1.82 & 0.51 & 2.02 & 0.00 & 1.30 & 0.72 & 1.42 & 0.29 & 1.58 & 0.11 & 1.82 & 0.00 & 1.55 & 0.35 \\
\hline 11 & 1.01 & 0.56 & 0.68 & 0.89 & 1.54 & 0.74 & 0.25 & 2.02 & 0.95 & 0.56 & 0.60 & 0.91 & 0.81 & 0.43 & 0.21 & 1.02 \\
\hline 12 & 1.17 & 0.00 & 0.33 & 0.84 & 1.44 & 0.33 & 1.50 & 0.26 & 0.87 & 0.00 & 0.75 & 0.12 & 0.91 & 0.19 & 0.21 & 0.89 \\
\hline 13 & 2.57 & 0.00 & 1.95 & 0.62 & 3.04 & 0.00 & 2.40 & 0.63 & 2.08 & 0.00 & 1.80 & 0.28 & 2.53 & 0.13 & 2.45 & 0.21 \\
\hline 14 & 3.04 & 0.00 & 1.66 & 1.38 & 3.54 & 0.00 & 1.70 & 1.84 & 2.23 & 0.00 & 1.54 & 0.69 & 2.53 & 0.00 & 1.60 & 0.93 \\
\hline 15 & 2.37 & 0.00 & 1.11 & 1.25 & 2.73 & 0.00 & 1.33 & 1.40 & 1.76 & 0.00 & 1.14 & 0.62 & 1.84 & 0.00 & 1.23 & 0.61 \\
\hline 16 & 2.59 & 0.00 & 1.98 & 0.61 & 2.69 & 0.00 & 1.41 & 1.21 & 1.66 & 0.00 & 1.43 & 0.23 & 2.02 & 0.00 & 1.37 & 0.65 \\
\hline 17 & 3.34 & 0.07 & 2.86 & 0.54 & 3.76 & 0.00 & 2.96 & 0.79 & 2.47 & 0.13 & 2.58 & 0.01 & 2.55 & 0.60 & 3.15 & 0.00 \\
\hline 18 & 2.29 & 0.00 & 0.59 & 1.69 & 2.43 & 0.00 & 0.58 & 2.65 & 1.42 & 0.00 & 0.64 & 0.78 & 1.48 & 0.00 & 0.47 & 1.01 \\
\hline 19 & 5.00 & 0.00 & 2.16 & 2.83 & 4.65 & 0.00 & 2.32 & 2.33 & 3.34 & 0.10 & 2.24 & 1.20 & 3.64 & 0.00 & 2.44 & 1.20 \\
\hline 20 & 4.86 & 0.00 & 2.13 & 2.72 & 5.97 & 0.00 & 2.82 & 3.14 & 3.54 & 0.00 & 1.83 & 1.71 & 3.44 & 0.00 & 1.53 & 1.90 \\
\hline 21 & 4.09 & 0.00 & 1.85 & 2.23 & 4.80 & 0.00 & 1.89 & 2.90 & 3.78 & 0.00 & 2.14 & 1.64 & 4.75 & 0.00 & 2.39 & 2.36 \\
\hline 22 & 6.43 & 0.00 & 3.82 & 2.61 & 6.56 & 1.50 & 2.17 & 5.89 & 3.84 & 0.00 & 2.83 & 1.02 & 4.25 & 0.00 & 2.85 & 1.40 \\
\hline 23 & 5.06 & 1.10 & 0.00 & 6.36 & 5.26 & 0.00 & 1.23 & 4.02 & 5.26 & 0.00 & 3.56 & 1.70 & 4.55 & 1.43 & 0.12 & 5.85 \\
\hline 24 & 5.81 & 0.00 & 3.51 & 2.28 & 6.88 & 0.00 & 4.31 & 2.56 & 4.15 & 0.00 & 2.83 & 1.33 & 4.45 & 0.00 & 2.99 & 1.46 \\
\hline Total & \multicolumn{16}{|c|}{ water } \\
\hline $\begin{array}{l}\text { consumption }^{- \text {plant }^{-1}}\end{array}$ & 3.04 & & & & 3.43 & & & & 2.42 & & & & 2.57 & & & \\
\hline
\end{tabular}




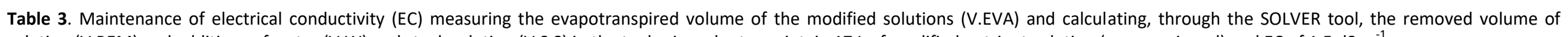
solution (V.REM) and additions of water (V.W) and stock solution (V.S.S) in the tanks, in order to maintain 17 L of modified nutrient solution (organomineral) and EC of 1.5 dS $\mathrm{m}^{-1}$.

\begin{tabular}{|c|c|c|c|c|c|c|c|c|c|c|c|c|c|c|c|c|}
\hline \multirow{2}{*}{$\begin{array}{l}\text { Evaluation, } \\
\text { days }\end{array}$} & \multicolumn{4}{|c|}{$\begin{array}{l}\text { Furlani (1995) - modified } \\
\text { (organomineral) }\end{array}$} & \multicolumn{4}{|c|}{$\begin{array}{l}\text { Bernardes (1997) - modified } \\
\text { (organomineral) }\end{array}$} & \multicolumn{4}{|c|}{$\begin{array}{l}\text { Ueda (1990) - modified } \\
\text { (organomineral) }\end{array}$} & \multicolumn{4}{|c|}{$\begin{array}{l}\text { Castellane and Araújo (1994) - modified } \\
\text { (organomineral) }\end{array}$} \\
\hline & V.EVA & V.REM & V.W & V.S.S & V.EVA & V.REM & V.W & V.S.S & V.EVA & V.REM & V.W & V.S.S & V.EVA & V.REM & V.W & V.S.S \\
\hline & \multicolumn{16}{|c|}{ } \\
\hline 1 & 0.00 & 0.00 & 0.00 & 0.00 & 0.00 & 0.00 & 0.00 & 0.00 & 0.00 & 0.00 & 0.00 & 0.00 & 0.00 & 0.00 & 0.00 & 0.00 \\
\hline 2 & 0.91 & 0.00 & 0.70 & 0.21 & 0.91 & 0.00 & 0.69 & 0.22 & 1.01 & 0.00 & 0.55 & 0.46 & 1.01 & 0.00 & 0.78 & 0.23 \\
\hline 3 & 1.21 & 0.00 & 0.89 & 0.32 & 0.91 & 0.00 & 0.71 & 0.20 & 0.81 & 0.00 & 0.50 & 0.31 & 0.91 & 0.00 & 0.60 & 0.31 \\
\hline 4 & 1.21 & 0.00 & 0.81 & 0.40 & 0.91 & 0.00 & 0.74 & 0.17 & 0.81 & 0.08 & 0.39 & 0.50 & 0.91 & 0.00 & 0.74 & 0.18 \\
\hline 5 & 1.92 & 0.00 & 1.28 & 0.63 & 1.60 & 0.00 & 1.15 & 0.44 & 1.48 & 0.00 & 0.90 & 0.57 & 1.60 & 0.00 & 1.18 & 0.42 \\
\hline 6 & 0.71 & 0.00 & 0.18 & 0.41 & 1.07 & 0.00 & 0.69 & 0.37 & 0.95 & 0.24 & 0.32 & 0.87 & 1.21 & 0.12 & 0.97 & 0.36 \\
\hline 7 & 0.51 & 0.00 & 0.14 & 0.18 & 1.09 & 0.00 & 1.16 & 0.26 & 0.61 & 0.47 & 0.07 & 1.00 & 0.73 & 0.00 & 0.59 & 0.13 \\
\hline 8 & 1.11 & 0.00 & 0.81 & 0.40 & 0.91 & 0.19 & 1.00 & 0.10 & 1.11 & 0.00 & 0.11 & 1.00 & 1.19 & 0.00 & 0.97 & 0.22 \\
\hline 9 & 1.62 & 0.00 & 0.89 & 0.72 & 2.21 & 0.00 & 1.58 & 0.63 & 1.82 & 0.00 & 1.37 & 0.45 & 1.52 & 0.00 & 1.28 & 0.24 \\
\hline 10 & 1.98 & 0.00 & 1.00 & 0.98 & 1.38 & 0.00 & 0.93 & 0.44 & 2.43 & 0.00 & 0.33 & 2.09 & 1.74 & 0.00 & 0.92 & 0.81 \\
\hline 11 & 1.25 & 0.77 & 1.96 & 0.07 & 0.65 & 0.24 & 0.80 & 0.09 & 2.23 & 0.28 & 0.31 & 2.19 & 0.91 & 0.39 & 1.06 & 0.24 \\
\hline 12 & 0.67 & 0.22 & 0.26 & 0.63 & 0.87 & 0.00 & 0.42 & 0.45 & 1.48 & 9.56 & 0.43 & 10.62 & 1.09 & 0.00 & 0.33 & 0.76 \\
\hline 13 & 2.39 & 0.00 & 1.63 & 0.75 & 1.21 & 0.00 & 0.96 & 0.25 & 2.99 & 0.00 & 0.81 & 2.18 & 1.52 & 0.00 & 0.97 & 0.54 \\
\hline 14 & 2.63 & 0.00 & 1.51 & 1.12 & 2.53 & 0.00 & 1.96 & 0.57 & 3.60 & 0.00 & 0.92 & 2.68 & 2.43 & 0.00 & 1.49 & 0.93 \\
\hline 15 & 1.84 & 0.00 & 1.05 & 0.79 & 1.23 & 0.00 & 0.64 & 0.32 & 2.63 & 0.16 & 0.00 & 2.79 & 1.78 & 0.00 & 1.10 & 0.67 \\
\hline 16 & 1.48 & 0.00 & 1.23 & 0.25 & 1.52 & 0.00 & 1.14 & 0.38 & 1.66 & 0.00 & 0.92 & 0.74 & 1.70 & 0.00 & 1.22 & 0.48 \\
\hline 17 & 3.36 & 0.00 & 2.25 & 1.11 & 2.10 & 0.01 & 1.61 & 0.49 & 3.30 & 2.93 & 0.00 & 6.23 & 3.36 & 0.00 & 2.34 & 1.01 \\
\hline 18 & 1.42 & 0.00 & 0.28 & 1.14 & 1.50 & 0.00 & 0.86 & 0.64 & 1.86 & 0.00 & 0.70 & 1.16 & 1.72 & 0.00 & 0.53 & 1.19 \\
\hline 19 & 4.35 & 0.00 & 2.72 & 1.63 & 1.94 & 0.12 & 1.97 & 0.09 & 4.39 & 0.00 & 0.84 & 3.53 & 3.97 & 0.00 & 2.68 & 1.29 \\
\hline 20 & 3.95 & 0.00 & 2.27 & 1.67 & 2.23 & 0.00 & 1.52 & 0.69 & 4.69 & 0.00 & 3.27 & 1.42 & 2.79 & 0.00 & 1.92 & 0.86 \\
\hline 21 & 3.10 & 0.00 & 1.80 & 1.30 & 1.66 & 0.00 & 1.28 & 0.37 & 3.88 & 13.12 & 0.12 & 16.88 & 3.14 & 0.00 & 2.12 & 1.01 \\
\hline 22 & 4.49 & 0.00 & 1.62 & 2.87 & 2.02 & 0.00 & 0.77 & 1.25 & 4.25 & 9.79 & 0.00 & 14.04 & 3.93 & 0.00 & 1.64 & 2.28 \\
\hline 23 & 4.69 & 0.25 & 1.88 & 3.06 & 2.33 & 0.00 & 0.91 & 1.41 & 5.16 & 3.28 & 3.30 & 6.23 & 4.25 & 0.00 & 1.70 & 2.54 \\
\hline 24 & 4.25 & 0.00 & 3.03 & 1.22 & 1.92 & 0.00 & 1.37 & 0.55 & 4.15 & 0.00 & 3.16 & 0.98 & 3.34 & 0.00 & 2.67 & 0.67 \\
\hline Total & & & & & & & & & & & & & & & & \\
\hline $\begin{array}{l}\text { consumption } \\
\text { L plant }^{-1}\end{array}$ & 2.55 & & & & 1.77 & & & & 2.86 & & & & 2.33 & & & \\
\hline
\end{tabular}




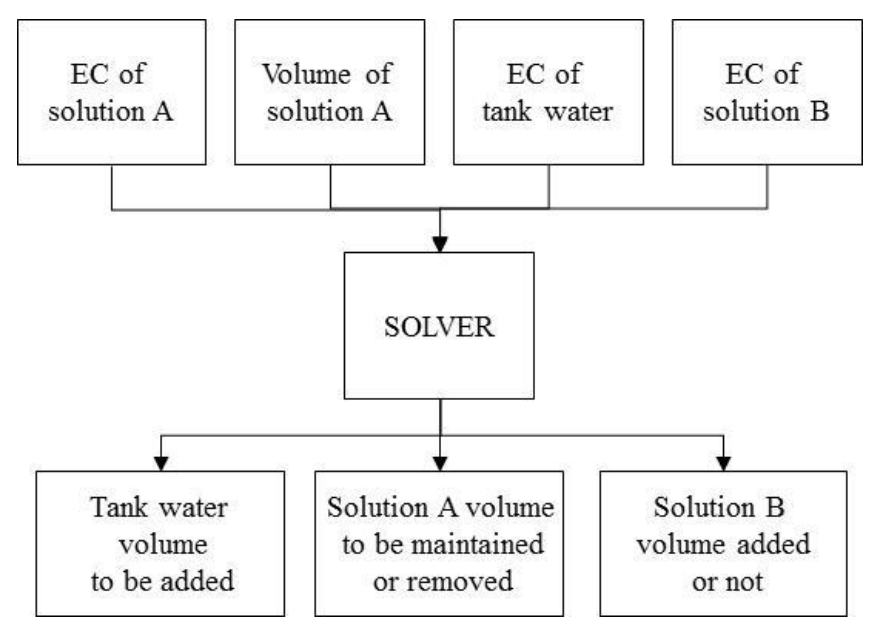

Fig 5. Flowchart of the calibration process of the nutrient solutions through the SOLVER tool. Solution of the tank that supplied the system (A) and stock solution (B).

nutrient solutions had EC higher than $1.5 \mathrm{dS} \mathrm{m}^{-1}$. Thus, the removal aimed to reduce the concentration of the nutrient solution by adding public-supply water.

Still according to Tables 2 and 3, the sum of the added volumes of tank water and stock solution corresponds to the evapotranspired volume, which led, at the end of each adjustment, to solutions with EC of $1.5 \mathrm{dS} \mathrm{m}^{-1}$ and volume of $17 \mathrm{~L}$. It is important to highlight that the EC, despite being correlated with the concentration, does not provide any estimate about the ionic balance of the solution. Thus, depending on cultivation purpose (commercial or scientific), crop to be planted and volume of the tank, the replacement of $100 \%$ of the nutrient solution becomes indispensable. In the present study, the replacements were made at intervals of 7 days. According to Braccini et al. (1999), the success of cultivation in NFT hydroponic system is achieved when the concentration, balance between cations and anions and $\mathrm{pH}$ of the nutrient solution exhibit few variations along the crop cycle.

In hydroponic systems, it is fundamental to manage the nutrient solution so that there are no major alterations in its composition, since it is constantly required by the crop. Unlike the soil, hydroponic systems do not have buffering capacity against the changes of concentrations in the root zone, which is a risk to be considered in a hydroponic production system. In the present study, there were alterations above and below the adjustment value of EC (1.5 dS $\mathrm{m}^{-1}$ ) in all nutrient solutions (Fig. 3), indicating concentration and dilution of nutrients in the solutions, respectively. The use of SOLVER as a helping tool in the daily calibration of the solutions was essential in their management, for reducing the time of calibration (it was not performed by trial and error), waste of solution and preventing possible nutritional disorders caused by significant alterations in the electrical conductivity.

It should be pointed out that the nutrient solutions represent a cost of production. Therefore, once used in hydroponic system, their concentration must be frequently monitored. According to Backes et al. (2004), the constant addition of nutrient solution with complete renewal of the solution has, as disadvantages, the waste of water and nutrients, and the polluting effect on the environment (especially nitrates and phosphates). Still according to the authors, the renewal of the solutions through the periodic addition of stock solutions reduces production costs without affecting production.

Materials and methods

\section{Experiment location and conduction}

The experiment was carried out in a hydroponic system adopting the nutrient film technique (NFT), in protected environment (greenhouse), at the Center of Agricultural and Environmental Sciences (CCAA) of the State University of Paraíba (UEPB), situated in the city of Lagoa Seca, Paraíba, at the following geographic coordinates: $7^{\circ} 10^{\prime} 15^{\prime \prime} \mathrm{S}, 35^{\circ} 51^{\prime}$ $14^{\prime \prime} \mathrm{W}$. According to the climatic classification of KöppenGeiger (Brasil, 1971), the climate of the municipality is characterized as humid tropical $\left(A s^{\prime}\right)$, with mean annual temperature around $22 \stackrel{\circ}{\circ}$, minimum of $18 \stackrel{\circ}{\circ}$ and maximum of $33 \stackrel{\circ}{\circ}$. The climatic data recorded during the experiment are presented in Fig. 2.

The experiment was conducted in randomized blocks with three replicates. The treatments consisted of eight nutrient solutions, four with chemical compositions proposed by Bernardes (1997), Castellane and Araújo (1994), Furlani (1995) and Ueda (1990), which were respectively referred to as BM, CM, FM and UM, and four solutions with chemical compositions similar to those of the previously cited ones, modified in the present research using biofertilizer in the composition, which led to four organomineral nutrient solutions, referred to as modified nutrient solutions of Bernardes (1997) (BO), Castellane and Araújo (1994) (CO), Furlani (1995) (FO) and Ueda (1990) (UO).. Each plot had two gutters spaced by $0.30 \mathrm{~m}$ and each gutter contained 10 plants of curly lettuce, spaced by $0.30 \mathrm{~m}$. Lettuce seedlings were produced in phenolic foam, by planting one pelleted seed per hole. After seedling emergence (SE), the tank water used in irrigation was gradually substituted by the nutrient solutions (33.33, 66.66 and $100 \%$ every four days). After 16 days of SE, the seedlings were transplanted to the definitive profiles.

\section{Preparation of the nutrient solutions}

The mineral nutrient solutions were prepared according to the methodology proposed by Ueda (1990), Castellane and 
Araújo (1994), Furlani (1995) and Bernardes (1997). The organomineral solutions were formulated using the SOLVER tool. For that, an electronic spreadsheet was created in Microsoft Office Excel containing the chemical composition of organic ingredients (bovine manure, bovine milk and poultry blood from the poultry slaughterhouse of the Agroindustrial complex of the CCAA/UEPB, and molasses purchased in the market of Campina Grande, Paraíba), inorganic ingredients (calcium nitrate, potassium nitrate, potassium phosphate, monoammonium phosphate, potassium chloride, magnesium sulfate and, in the form of sulfate, the micronutrients copper, zinc, manganese and iron) and the chemical composition of the nutrient solution to be formulated according to the treatments.

After formulation, the modified solutions underwent aerobic maturation for 30 days. Aeration was performed using an air compressor, at 15-min intervals, which guaranteed a dissolved oxygen concentration close to 2.0 $\mathrm{mg} \mathrm{L} \mathrm{L}^{-1}$ and, consequently, the action of aerobic microorganisms. During the experiment, the solutions that supplied the hydroponic cultivation profiles were calibrated through daily readings of electrical conductivity $(E C)$ and $\mathrm{pH}$. The EC was maintained at $1.5 \mathrm{dS} \mathrm{cm}^{-1}$ and the $\mathrm{pH}$ between 6.0 and 7.0. Regardless of the treatments, the nutrient solutions were replaced in equidistant periods of 7 days. The nutrient solution that supplied the cultivation gutters was stored in plastic buckets with capacity for $20 \mathrm{~L}$; however, to avoid waste of solution due to overflowing in the bucket, a volume of $17 \mathrm{~L}$ was used. To maintain the nutrient solution within the temperature limits recommended for hydroponic cultivation, the buckets containing the solution were coated with a 5-mm-thick ethylene-vinyl acetate (EVA) foam.

\section{Optimization model structure}

The structure of the mathematical optimization model used in the present research is linear programming, implemented in Excel, using the SOLVER tool. This tool is available in the Microsoft Office Excel and, to activate it, just click Add-ins on the Tools menu and mark the Solver check box. Click OK and Excel will install the Solver tool. After installation, the Solver tool will be available on the Tools menu. The study on linear programming allows the efficient distribution of limited resources existing in many competitive activities whose objective is to obtain a maximization and/or minimization of a dependent variable, which is a linear function of various independent variables, called objective function, subject to a series of linear equations (or inequations), called restrictions. According to Corrar and Garcia (2001), the minimization model can be represented by Equation 1:

Min. $Z=C_{1} X_{1}+$

$\mathrm{C}_{2} \mathrm{X}_{2}+\ldots \ldots \ldots \mathrm{C}_{\mathrm{n}} \mathrm{X}_{\mathrm{n}}$

Subject to a series of restrictions:

$A_{11} X_{1}+A_{12} X_{2}+\ldots \ldots \ldots \ldots . . . . . . A_{1 n} X_{n} \leq$ or $=$ or $\geq$ b1 (Restriction 1$)$

$A_{21} X_{1}+A_{22} X_{2}+\ldots \ldots \ldots \ldots . . . . . A_{2 n} X_{n} \leq$ or $=$ or $\geq b 2$ (Restriction 2)

$A_{m 1} X_{1}+A_{m 2} X_{2}+\ldots \ldots \ldots \ldots . . . . A_{m n} X_{n} \leq$ or $=$ or $\geq$ bm (Restriction $n$ )

Where;

$x i \geq 0$ and $b i \geq 0$, for $i=1,2, \ldots . n$ and $j=1,2, \ldots m$;

$Z$ : function to be minimized, respecting the set of restrictions; xi: decision variables that represent the quantities or resources to be determined to optimize the global result;

ci: cost of each variable;

bj: limit to be achieved; and,

aij: quantity of resources that each decision variable provides.

\section{Objective function}

In the present study, the objective function was the optimization of the process of calibration and maintenance of the electrical conductivity and daily volume of the different nutrient solutions.

\section{Monitoring and calibration of the nutrient solutions}

Monitoring was daily performed, at 24-h interval, with readings of electrical conductivity (EC), hydrogen potential $(\mathrm{pH})$, temperature $(14: 00 \mathrm{~h})$ and volume of the solutions that supplied the system, using a $\mathrm{pH} / \mathrm{EC} / \mathrm{TDS} /{ }^{\circ} \mathrm{C}$ meter, model $\mathrm{HI}$ 9811-5. The volume of the solution that supplied the system was estimated by subtracting the volume recorded after 24 $h$ from the initial volume of solution (17 L).

The solutions were maintained considering the variation in their nutritional concentration, through the estimate of EC using the SOLVER tool, and the mathematical model was the same previously described in the preparation of the solutions. An electronic spreadsheet was created and received the data referring to electrical conductivity $(E C)$ of the nutrient solutions that supplied the system (A), tank water used to prepare the solutions $(A)$ and concentrated stock solution (B), as well as the volume of nutrient solution (A). These data were daily collected. In this case, the objective value of the optimization was the minimization, having as requirements solutions with $\mathrm{EC}$ of $1.5 \mathrm{dS} \mathrm{m}^{-1}$ and volume of $17 \mathrm{~L}$. For that, restrictions of equality were used and, in a simplified way, the process of calibration of the solutions occurred according to the flowchart presented in Fig. 5. After calibration, the $\mathrm{pH}$ of the solutions was adjusted to be maintained close to neutrality, using a solution of $\mathrm{NaOH}$ or $\mathrm{H}_{2} \mathrm{SO}_{4}\left(1 \mathrm{~mol} \mathrm{~L}^{-1}\right)$. The graph of $\mathrm{pH}$ variation was created considering the mean molar concentration of the $\mathrm{H}^{+}$ ions, using the expression $\mathrm{pH}=-\log \left[\mathrm{H}^{+}\right]$.

\section{Nutrient solution consumption by lettuce plants}

The volume evapotranspired by the plants $\left(\mathrm{V}_{\mathrm{ETC}}\right)$, as a function of the nutrient solutions, was daily quantified by replenishing the tank volume until the level of $17 \mathrm{~L}$, using a cylinder graduated in millimeters, according to Equation 2. The $V_{\mathrm{ETC}}$ was considered as quantitative variable to establish a polynomial regression analysis.

$$
\mathrm{V}_{\mathrm{ETc}}=\frac{\sum \mathrm{Vi}}{\mathrm{n} \Delta \Delta}
$$

Where:

$\mathrm{V}_{\mathrm{ETC}}$ - evapotranspired volume, in $\mathrm{L} \mathrm{plant}^{-1}$ day $^{-1}$;

$\mathrm{Vi}$ - solution volume consumed in the time interval of $24 \mathrm{~h}$;

$\Delta T$ - time interval between the readings, days; and,

$n$-number of plants in the profile in the time interval, $\Delta T$. 


\section{Statistical analysis}

For the data of hydrogen potential $(\mathrm{pH})$, electrical conductivity (EC) and temperature, dispersion graphs were constructed and, for water consumption, analysis of variance (ANOVA) was performed by $F$ test. When there was significant effect, polynomial regression was applied, according to the treatments, using the statistical program SISVAR (Ferreira, 2014).

\section{Conclusion}

The temperature of the nutrient solutions, both mineral and organomineral, exhibited acceptable variations for lettuce cultivation. The $\mathrm{pH}$ variation was lower in the modified nutrient solutions. However, after each replacement, it was necessary to correct the $\mathrm{pH}$ to values close to 7.0 , before being used in the hydroponic system. The lettuce crop consumed greater volumes of mineral solution, in comparison to organomineral solutions of same chemical composition. The SOLVER tool was efficient and of easy utilization in the process of calibration and maintenance of electrical conductivity and volume of the nutrient solutions, requiring data that are frequently measured in hydroponic systems.

\section{Acknowledgments}

The authors thank the State University of Paraíba, for its contribution through the PROPESQ program to conduct this research.

\section{References}

Alves MS, Soares TM, Silva LT, Fernandes JP, Oliveira, MLA, Paz VPS (2011) Estratégias de uso de água salobra na produção de alface em hidroponia NFT. Rev Bras Eng Agríc Ambient. 15: 491-498.

Al-Hamdani SH, Ghazal JJ (2009) Selected physiological responses of Salvinia minima to various temperatures e light intensities. Am Fern J. 99: 155-161.

Backes FAAL, Santos OS, Pilau FG, Bonnecarrère RAG, Medeiros SLP, Fagan EB (2004) Reposição de nutrientes em soluções nutritivas no cultivo hidropônico de alface. Cien Rural. 34: 1407-1414.

Barbieri E, Melo DJF, Andrade LF, Pereira EWL, Cometti NN (2010) Condutividade elétrica ideal para o cultivo hidropônico de alface em ambiente tropical. Hortc Bras. 28: 303-308.

Beninni ERY, Takahashi HW, Neves CSVJ (2005) Concentração e acúmulo de macronutrientes em alface cultivada em sistemas hidropônico e convencional. Ciên Agrar. 26: 273-282.

Bernardes LJH (1997) Hidroponia da alface: uma história de sucesso. São Paulo, Estação Experimental de Hidroponia "Alface e Cia".

Braccini MCL, Braccini ALE, Martinez HEP (1999) Critérios para renovação ou manutenção de solução nutritiva em cultivo hidropônico. Cien Agrar. 20: 48-57.

Brasil (1971) Ministério da Agricultura. Equipe de Pedologia e Fertilidade do Solo. Levantamento exploratório.
Reconhecimento de solos do estado da Paraíba. Rio de Janeiro, SUDENE, 670p. (Boletim Técnico, 15).

Castellane PD, Araújo JAC (1994) Cultivo sem solo: hidroponia Jaboticabal, FUNEP.

Cometti NN, Bremenkamp DM, Galon K, Hell LR, Zanotelli MF (2013) Cooling and concentration of nutrient solution in hydroponic lettuce crop. Hortic Bras. 31: 287-292.

Corrar LJ, Garcia EAR (2001) Programação linear: uma aplicação à contabilidade de custos no processo de tomada de decisão. Trabalho apresentado no 70 Congresso internacional de custos, Universidad de Leon, Leon, 4-6 de julho de 2001.

Dias NS, Brito AF, Sousa Neto ON, Lira RB, Brito RF (2009) Produção de alface hidropônica utilizando biofertilizante como solução nutritiva. Rev Caatinga. 22: 158-162.

Dobbss LB, Canellas LP, Alleoni LRF, Rezende CE, Fontes M PF, Velloso ACX (2008) Eletroquímica de latossolos brasileiros após a remoção da matéria orgânica humificada solúvel. Rev Bras Ciên Solo. 32: 985-996.

Factor TL (2007) Produção de minitubérculos de batatasemente em sistemas hidropônicos $\mathrm{nft}$, $\mathrm{dft}$ e aeroponia. 120f. Tese (Doutorado em agronomia). Faculdade de Ciências Agrarias e Veterinárias (UNESP), Jaboticabal, São Paulo.

Ferreira DF (2014) Sisvar: a guide for its bootstrap procedures in multiple comparisons. Ciênc Agrotec. 38:109-112.

Fonseca MCM, Raslan KR, Martinez HEP, Pereira PRG, Barbosa JG (2005) Tamponamento do pH da solução nutritiva na hidroponia de plantas ornamentais. Rev Bras Hortc Orn. 11: 100-108.

Furlani PR (1995) Cultivo de alface pela técnica de hidroponia - NFT. Campinas, IAC, 18p. (IAC Documentos 55).

Furtado LF (2008) Vazões de aplicação de solução nutritiva, teor de nitrato em alface sob cultivo hidropônico e aceitabilidade sensorial. 71f. Dissertação (Mestrado em Engenharia Agrícola). Universidade Estadual do Oeste do Paraná (UNIOESTE), Cascavel, Paraná.

Genuncio GC, Gomes M, Ferrari AC, Majerowicz N, Zonta E (2012) Hydroponic lettuce production in different concentrations e flow rates of nutrient solution. Hortc Bras. 30: 526-530.

Gomes LS, Martins CAS, Nogueira NO, Lopes FS, Xavier TMT, Cardoso LCM (2011) Efeito de diferentes valores de pH da solução nutritiva no desenvolvimento de variedades de melão. Rev Bras Ciên Agrar. 6: 73-78.

Gondim ARO, Flores MEP, Martinez HEP, Fontes PCR, Helbel Junior C. Rezende R, Santos HS, Freitas PSL, Azevedo TLF, Frizzone JA (2010) Soluções nutritivas, vazões e qualidade da alface hidropônica. Acta Sci Agron. 29: 291-295.

Helbel Junior C, Rezende R, Frizzone JA, Santos HS, Dallacort, R (2007) Produção hidropônica da cultura da alface com soluções nutritivas e vazões distintas. Acta Sci Agron. 29:391-395.

Lopes MC, Freier M, Matte JC, Gärtner M, Franzener G, Casimiro NEL, Sevignani A (2003) Acúmulo de nutrientes por cultivares de alface em cultivo hidropônico no inverno. Hortc Bras. 21: 211-215.

Martinez HEP, Braccini MCL, Braccini AL (1997) Cultivo hidropônico do tomateiro (Lycopersicon esculentum Mill.). Rev Unimar. 19: 721-740. 
Martinez HEP, Clemente JM (2011) O uso do cultivo hidropônico de plantas em pesquisa. Viçosa, UFV, 61p. (Série Didática 1)

Mohammed AR, Tarpley L (2009) High night time temperatures affect rice productivity through altered pollen germination e spikelet fertility. Agric For Meteorol. 149: 999-1008.

Monteiro Filho AF, Azevedo MRQA, Azevedo CAV, Fernandes JD, Silva CR, Silva YS (2017) Growth of hydroponic lettuce with optimized mineral and organomineral nutrient solutions. Rev Bras Eng Agri Ambiet. 21: 191-196.

Monteiro Filho AF, Pereira GL, Azevedo MRQA, Fernandes JD, Azevedo CAV (2014) Cultivo hidropônico de cultivares de alface em soluções nutritivas organominerais otimizadas com a ferramenta SOLVER. Rev Bras Eng Agríc Ambient. 18: 417-424.

Paulus D, Dourado Neto D, Frizzone JA, Soares TM (2010) Produção e indicadores fisiológicos de alface sob hidroponia com água salina. Hortc Bras. 28: 29-35.

Paulus D, Paulus E, Nava GA, Moura CA (2012) Crescimento, consumo hídrico e composição mineral de alface cultivada em hidroponia com águas salinas. Rev Ceres. 59: 100-117.

Ribeiro KS, Ferreira E, Costa MSSM, Gazola D, Szimanski C (2007) Uso de biofertilizante no cultivo de alface hidropônica. Rev Bras Agroec. 2: 160-164.

Sanchez SV (2007) Avaliação de cultivares de alface crespa produzidas em hidroponia tipo NFT em dois ambientes protegidos em Ribeirão Preto (SP). 63f. Dissertação (Mestrado em Agronomia) Faculdade de Ciências Agrarias e Veterinárias (UNESP), Jaboticabal, São Paulo.

Sanches CEJ, Araújo JAC, Spelling AC, Villela Junior LVE (2005) Cultivo hidropônico da alface do grupo americana com resfriamento da solução nutritiva. Trabalho apresentado no $45^{\circ}$ Congresso Brasileiro de Olericultura, FAPESP, Fortaleza, 07-12 de Agosto de 2005.

Santos D, Mendonça RMN, Silva SM, Espínola JEF, Souza AP (2011) Produção comercial de cultivares de alface em Bananeiras. Hortc Bras. 2: 609-612.

Santos RNC, Minami K (2002) Cultivo Hidropônico do Meloeiro. Piracicaba, ESALQ, 38 p. (Serie Produtor Rural).

Sarmento JDA, Morais PLD, Almeida MLB, Sousa Neto ON, Dias NS (2014) Qualidade e conservação da alface cultivada com rejeito da dessalinização, Rev Caatinga. 27: $90-97$.

Silva AO, Soares TM, Silva ÊFF, Santos NA, Klar AE. (2012) Consumo hídrico da rúcula em cultivo hidropônico NFT utilizando rejeitos de dessalinizador em Ibimirim-PE. Irriga. 17: 114-125.

Soares TM, Duarte SN, Silva EFFE, Jorge CA (2010) Combinação de águas doce e salobra para a produção de alface hidroponica. Rev Bras Eng Agríc Ambient. 14: 705714.

Sutton JC, Sopher CR, Owen-Going TN, Liu W, Grodzinski B, Hall JC, Benchimol RL (2006) Etiology e epidemiology of Pythium root rot in hydroponic crops: current knowledge e perspectives. Summa Phytopathol. 32: 307-321.

Ueda S (1990) Hidroponia: guia prático. São Paulo, Agroestufa.

Wahid A, Gelani S, Ashra M, Foolad MR (2007) Heat tolerance in plants: An overview. Enviro Exp Bot. 61: 199223.

Yang J, Kong Q, Xiang C (2009) Effects of low night temperature on pigments, chl a fluorescence e energy allocation in two bitter gourd (Momordica charantia L.) genotypes. Acta Physiol Plant. 31: 285-293, 2009. 